Vladimir Bakrač

\title{
RELIGIJA U RALJAMA POLITIKE ${ }^{1}$
}

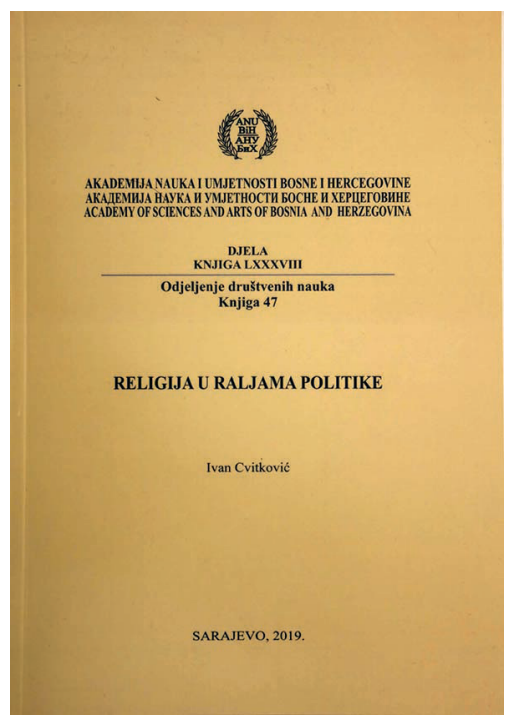

Ove (2019) godine, u izdanju Akademije nauka i umjetnosti Bosne i Hercegovine, iz štampe je izašla knjiga Religija u raljama politike prof. dr Ivana Cvitkovića, redovnog profesora i akademika. Ovdje je riječ, zapravo, o vrlo analitičnom, opsežnom i nadasve erudiranom djelu o odnosima religije i politike, uobličenom teorijskim analizama i empirijskim ekspertizama.

U svojoj ljubopitljivosti, zainteresovao sam se kako se religija našla u raljama politike, prema Cvitkovićevom spisu? Da li je politika, po ko zna koji put zlo/upotrijebila religiju, ili je, pak, religija poklekla pod ovozemaljskim interesima? Kako bih bio što egzaktniji, naglasiću da društveno-povijesne svjedodžbe detektuju miješanje religije u politiku i uplitanje politike u ono što je religija i religijsko. Otkako je car Konstantin počeo da predsjedava Vaseljenskim saborom, sklopljen je brak između religije (hrišćanstva) i politike, taj brak traje i danas, a kao i svaki brak iz nužde, prepun je trzavica, nepočinstava, oportunizma, nedozvoljenog flerta i sa jedne i sa druge strane. Razmišljajući na sljedeći način: ako se religija ne bi bavila politikom, onda će se, mislim, politika baviti religijom, pa svoj mentalni sklop izlažem dilemi, ne očekujući brz i jednostavan rasplet da li religija može bez politike, kao i da li politika može bez religije? Stiče se utisak da jedna bez druge ne mogu, dok jedna sa drugom ne umiju - izgleda da je jedina opcija da budu jedna pored druge, a Isus kaže da "moje carstvo nije od ovog svijeta"! Virtuozi akademskog poziva koji se bave ovom problematikom nijesu oklijevali u analizi ova dva pojma, a jedan od njih je, dakako,

\footnotetext{
${ }^{1}$ Prikaz knjige Religija u raljama politike. Religija\&tolerancija, Novi Sad, god. XVII, br. 31/2019, str. 175-181.
} 
Ivan Cvitković, koji je brojne temate gdje se religija i politika prepliću sistematizovao u knjizi za koju pišemo prikaz.

Dosledan svom ateističkom ubjeđenju, čiju sjenu naslućujemo u svim poglavljima knjige, Cvitković nepokolebljivo ostaje vjeran i neutralnom religijskom pristupu, oslobođen agitpropskih ambicija, dopuštajući jedino metodološkom agnosticizmu da ovlada njegovim akademskim razmišljanjima, na temu koja ga je inspirisala. Ne treba da čudi zašto se autor bavio odnosima religije i politike, budući da je protagonista zbilje, neko ko je težinu ovog susreta doživljavao i preživljavao lično. Stoga, nakon rutiniranih analiza, autor kiriološkim prilozima ne zaobilazi religijski pejzaž u Bosni i Hercegovini. Rukopis Ivana Cvitkovića ne bismo mogli opisati kao katehizmus, već opsežno djelo koje, kroz dvanaest poglavlja, apodiktično analizira korelaciju religijsko-političkog temata.

U protazi knjige, autor partimentno objašnjava zašto je oštricu svog pera usmjerio na egzegezu odnosa religije i politike, nalazeći motiv u činjenici da i jedna i druga imaju i te kako veliki društveni uticaj i moć. Religijske odluke imaju moralni i simbolički značaj, ali zbog povezanosti religije i politike u novijim sukobima, moć crkve i religijskih zajednica ne treba potcjenjivati. Autor se eksplicitno usredsređuje na odnos religije i politike na balkanskoj vjetrometini, a razlog za analizu ove vrste nalazi u činjenici da je riječ o području gdje vlada multikonfesionalnost. Esperto religijske slike i prilike na ovim prostorima, nadahnjujući bosanskohercegovački akademik, koloritno je oživopisao doživljenost odnosa religije i politike, kao dva mača koja bdiju nad glavom stanovnika bosanskohercegovačke kasabe. Apodiktično se apostrofira činjenica da religija ima višeznačnu ulogu u političkom životu u kojem nedvosmisleno jača konzervativni pravac. Na taj način uramljena, religija može biti zlo/upotrijebljena u političkim interesima.

Dosljedan svom istraživačkom naukovanju, autor u prvom poglavlju izgrađuje svojevrsni pojam o pojmu koji proučava. Akumuliranim teorijskim znanjem i višedecenijskim istraživačkim vještinama, autor analizira odnos politike i morala, primjećujući da onaj ko želi slobodu mišljenja bježi od politike. Ko nije ni u jednoj stranci, nije ni na čijoj strani! U tom kontekstu, vispreno zapaža autor, etičke odgovornosti u politici nema. Važno je istaći zapažanje kako političke stranke često instrumentalizuju religiju, koristeći uticaj religije u predizbornim kampanjama, dok, s druge strane, i religijama odgovara takav, mislim, oportunistički način ophođenja, željno iščekujući ovozemaljske darove. Sve ide u prilog činjenici da su granice između religije i politike difuzne, što može voditi do povećanja napetosti i tenzija. Kako religija važi za nešto što njeguje konzervativne i tradicionalne vrijednosti, ona 
može biti pogodan pokretač i vjetar u leđa za buđenje biračkog tijela onih političkih stranaka koje propagiraju desničarski opus.

U skladu sa zadatim tematom, Cvitković dodatno izoštrava sliku u drugom poglavlju, minuciozno razrađujući odnos između religije i politike s jedne, kao i razliku između crkve i države s druge strane. Crkva i država imaju sličnosti jer i jedna i druga šire strah među ljudima, prva božijim kaznama, a druga zakonima. Ostajući vjeran sociološkom diskursu, autor nastavlja da inauguriše značaj i značenje integrativne funkcije religije u društvu, primjećujući da religija može da ima i dezintegrativnu ulogu - može da spaja, ali i da dijeli! Oštricu akademskog pera usmjerava i na područje prava, gdje se naučnoj ekspertizi podvrgavaju pitanja o odnosu crkve i država s jedne te prava i religije s druge strane. $U$ tom kontekstu u fokus analize izranja nekoliko pitanja: pojam teokratije, gdje se politički vođa izdaje za božijeg namjesnika, a religijski poglavar za političkog moćnika. Pravo prepoznaje model priznatih religija, gdje se izdvajaju određene religije koje uživaju jednaka prava i blagodeti države, dok se u supsidijarnom položaju nalaze sve druge religije. Razmatra se model odvojenosti države od religijskih zajednica. Analizirajući mogućnost jednog takvog idejnog poretka, autor zapaža, kako je taj model različit u različitim državama. U pojmovnoj preciznosti, autor ide i korak dublje, praveći razliku između sekularizma i sekularizacije, naglašavajući ideološku dimenziju sekularizma, nasuprot sekularizacije kao prirodnog procesa, bez ideoloških i političkih pritisaka. Ne izostaje ni kritički osvrt na ustavno-pravni sistem Bosne i Hercegovine, koja garantuje novčane nagrade za vjerske praznike, dok to isto ne čini za državne, dovodeći time u pitanje jednakopravnost svih građana.

Za jednog sociologa ili politikologa lako je dati odrednicu demokratije - vladavina naroda! Ako bismo demokratiju determinisali kao vladavinu većine, šta je onda s pravima manjine, pita se Cvitković u trećem poglavlju knjige? Džon Koton kaže: “Ako bi demokratija bila vladavina naroda, kime bi oni vladali”? Vladavina u ime naroda uvijek može da sklizne u vladavinu nad narodom! Gledajući kroz idealno tipsku prizmu, demokratija podrazumijeva teren za razvoj religijskog pluralizma, gdje se umnožava sloboda misli, savjesti i vjeroispovijesti. Sloboda jeste zakonito čedo demokratije i njeno najveće dobro, besjedi Platon u Državi, pa upozorava da bi nezasitost u onome što smatramo najvećim dobrom mogla uništiti demokratiju. Sloboda nema svoju vrijednost, zapaža Cvitković, ako su prava pojedinaca ograničena. Različite religije imaju različit pogled na demokratiju. Upečatljiv je autorov govor u analizi protestantizma i demokratije, apostrofirajući činjenicu kako je parlamentarna demokratija najdalje otišla u dominantno protestantskim zemljama. 
Interesantan je osvrt na islam i demokratiju. Nije rijetka svojevrsna disputacija među teoretičarima o tome da li se islam može vezivati za demokratiju ili je riječ o religiji gdje je demokratija "strano tijelo". Dok je demokratija per definitionem vladavina naroda, za islamski svijet Allah vlada a ne narod, percipirajući demokratiju kao idolopoklonstvo, objašnjava Cvitković. Međutim, zaboravljaju se neke nedemokratske vrijednosti, poput diktature, koje baštini i Evropa, kolijevka demokratije. U osvrtu na bosanskohercegovačku zbilju, autor opominje da je na snazi "plebiscitarna demokratija" gdje građani izlaze samo na izbore, a da je na snazi politizacija, što znači odsustvo demokratije i prisustvo odlučivanja na najvećem stranačkom nivou. Govor o odnosu religije i demokratije autor zaključuje onim po čemu je i prepoznatljiv stručnoj religiološkoj eliti na ovim prostorima. Naime, autor opominje na dijalog kao jedini put povjerenja i pomirenja među religijama.

U uporednoj analizi religije i politike, autor se lapidarno zadržao i na izborima, pokazujući i dokazujući još jednu sponu gdje religija i politika nalaze međusobni interes. Ne treba zanemariti ulogu religije u predizbornim agitacijama i u razvijenim zemljama Zapada. Napomenimo samo ulogu "moralne većine" u izbornoj kampanji Ronalda Regana, ili u izbornoj trci Džordša Buša mlađeg, koji je, kao pobornik kreacionizma, nastojao da motiviše veliki broj građana iz redova religijskog konzervativizma da upravo njemu povjere glas. Ni drugi politički sistemi se ne mogu amnestirati od prizivanja religije u svrhe stranačke propagande. Međutim, sve religije ili religijske zajednice, kako precizira Cvitković, podršku će dati onim strankama koje obezbjeđuju garanciju vjerskih pouka u obrazovnim institucijama, koje se protive istopolnim brakovima, abortusu i sl. Dakle, reciprocitet po učinku, učini ti meni, pa ću učiniti i ja tebi!

Ne izmiče analizi ni odnos religije i siromaštva. Poznato je da su mnoge religije, prije nego što su postale moćne, nastale među nemoćnima u materijalnom smislu. Isus je svoje prve učenike nalazio među tesarima, ribarima itd., rekavši "podaj sve pa pođi za mnom". Gautama Sidarta je bio plemić koji se odrekao svega i krenuo stazama monaštva. Iako je hrišćanstvo religija siromašnih, autor znalački bilježi da jevanđelista Matej apostrofira siromaštvo duhom, jer je njihovo carstvo nebesko. Nijesu više u pitanju "gladni i žedni”, tvrdi autor, jevanđelista zaobilazi prokletstvo bogataša. Socijalna politika je zastupljena u skoro svim svetim spisima, nastavlja Cvitković, pa podsjeća na to da je Stari zavjet propisao davanje desetka od ukupnog imetka, a Kuran spominje zekat, odvajanje za siromašne od svog bogatstva. Na kraju, treba spomenuti da religija svoje pristalice nalazi u poniženim i uvrijeđenim: što je neka država siromašnija, veći je postotak vjerničke populacije u njoj. 
Pomalo je paradoksalno religiju povezati sa nasiljem. Otkuda nasilje u religiji, ako je katehizis gotovo svih religija miroljubiv? Istina, smatra Cvitković, da se u starozavjetnim spisima često pominje nasilje, dok se u Kuranu, svetoj knjizi islamske zajednice, riječ džihad upotrebljava četrdeset jedan put, od čega se deset puta odnosi na ratovanje. Osvrćući se na bosanskohercegovačku zbilju devedesetih godina minulog vijeka, autor bilježi riječi vrijedne pomena da "u svakom ratu prvo gine istina". Teško je zamisliti rat u ime religije, kakav bi to bio Bog, ako bi podržao rat, mržnju i nesreću nedužnih ljudi? Otuda Ivan Cvitković kaže "svaki rat u ime religije (bilo koje) je rat protiv religije". Ne prepušta se talasima zaborava ni činjenica da postoji neki oblik nasilja u samim religijama, misleći na glorifikaciju žrtve, kao svojevrsni oblik nasilja. Takođe, svojevrsnoj analizi je podvrgnut i terorizam, koji se u savremenoj sociološkoj periodici, negdje od dolaska Homeinija na vlast, vezuje za muslimane. Ostajući dosljedan preciznosti i objektivnosti, autor se priklanja tezi da "i ako jesu svi teroristi muslimani, nisu svi muslimani teroristi", tvrdeći da se religija zloupotrebljava za neke političke ciljeve i interese. Završavajući tekst o nasilju u ime religije, primjetan je vrlo objektivan stav koji prepoznajemo u činjenici da smo svi skloni da apostrofiramo nasilje nad nama, dok nasilje koje smo mi počinili predajemo vihoru zaborava.

Već u nazivu narednog poglavlja "Politika ismijavanja religije" naslućujemo u kojem pravcu će Cvitković praviti komparaciju religija - politika. Svoj istraživački elan je usmjerio na razgraničavanje pojmova smijeh i ismijavanje. Smijeh i religija pripadaju samo čovjeku, primjećuje autor. Ismijavati religije druge i drugačije od svoje je moralno upitno, a može dovesti do podizanja tenzija i voditi ka zaoštravanju sukoba. Ovdje je riječ o vrijeđanju najranjivijih osjećanja među pripadnicima jedne religije. No, to ne znači da iz domena šale i humora treba da budu amnestirane institucije religijskih zajednica, sveštenici, imami itd.

Vođen pređašnjim rukopisom, autor se osvrće i na pojam blasfemije ili bogohuljenja, prihvatajući obeščašćenje nečega što jedna zajednica smatra svetim kao odrednicu blasfemičnosti. U završnoj perikopi, autor vispreno zaključuje kako je on lično za potpunu slobodu, ali da je granica moje slobode vjerska sloboda drugog!

U rukopisu se razmatra odnos pojedinih ideologija i njihovih religijskih osobina. Odnosno, kako su te ideologije postale svojevrsne političke religije. Pokušava se staviti znak jednakosti između komunizma i nacizma, čime, mislim, autor pravi jednu kritičku grimasu prema postmoderni. Naime, posmodernisti tvrde da su sva iskustva podjednako vrijedna, ne postoji nešto što je dobro ili loše, postoji samo različito. U takvom razumijevanju, između 
nacizma i socijalizma možemo stavljati znak jednakosti. Kod Cvitkovića se tačno prepoznaju vrijednosti koje apostrofiraju te ideologije. On ne odbacuje odgovornost i jedne i druge ideologije, samo upozorava na neprecizan, neobjektivan i pristrasan odnos, glorifikacije jedne nauštrb druge. Cvitković se ne distancira od odgovornosti svih ideologija, već ih samo posmatra sa jednog univerzalnog stajališta, što mu omogućava da uvede kriterijume za razlikovanje i sličnosti. Sličnosti između ideologija se analiziraju na simboličkoj ravni, potom na nekim nepočinstvima baziranim na nacionalnoj, rasnoj, religijskoj i ideološkoj razini. Lociranje istorijskog perioda nastanka ovih ideologija u prvu polovinu dvadesetog vijeka posmatra se samo kao još jedna sličnost među njima. Vođen Žižekovim ubjeđenjem, naglaša mišljenje da treba praviti razliku između staljinizma i nacizma. Ne poriču se neke sličnosti između marksizma i nacizma, ali "njihove biološke i psihološke teorije bile su posve oprečne". Ko nije spreman da razgovara o pošastima koje su iznjedrile neke ideologije, poput ustaštva, četnika itd., ne treba da vodi razgovor o socijalizmu, ubijeđen je autor.

U ovoj alineji apostrofira se činjenica da je istinski raskid između crkve i države, odnosno države gdje je ta ideologija bila dominantna, napravio socijalizam. U sveobuhvatnoj analizi autor podvodi kritici pojedine vjerske zajednice, koje su nekritičkim tonom pristupile zločinima - nijedna vjerska zajednica nije osudila zločine počinjene u sopstvenim redovima. Važno je i meni interesantno zapažanje autora da, u ovom poglavlju, nije izostavljena ni empirijska analiza, na osnovu koje kritički promatra bilans promjena u pojedinim bivšim jugoslovenskim republikama.

Nakon što nam je predstavio panoramski pogled o odnosu komunizma i religije, nazivajući ih "političkim religijama", autor precizira pojam ateizam. Teško je dati preciznu odrednicu ateizma. Ako pođemo od stava da je ateista onaj ko ne vjeruje u Boga, to još ne znači da i on nije vjernik, budući da on samo vjeruje da Boga nema. Često se pitam da li je za ateizam potrebno malo više vjere nego za religiju, da li je ateizam uopšte moguć? Džulijan Barns kaže: "Ne vjerujem u Boga, ali mi nedostaje"! Posmatrano hronološki, ateističke ideje nijesu novijeg datuma. Naime, mnogi starogrčki filozofi, poput Anaksagore, Kritija, Demokrita itd., bili su protjerivani zbog nevjere u bogove, a Sokrat je bio optužen za bezbožnost. Sva djeca su ateisti, jer nemaju predstavu o Bogu, domišljato objašnjava Cvitković. Neki vjerski spisi osuđuju ateizam, no, primjećuje Cvitković, ako se Novi zavjet protivi osuđivanju različitih mišljenja, zašto apostol Pavle u jednoj od poslanica govori o "udaljavanju od nevjernika"? Dosljedan svom akademskom principu, autor analizira brojne tipove ateizma, zaključujući poglavlje promatranjem statusa 
ateiste u društvu. U tom kontekstu konstatuje da je biti ateista poželjno ako to zadržavaš za sebe, navodeći epistemološke podatke, gdje ateista dijeli mjesto sa najomraženijim i najnepoželjnijim društvenim kategorijama.

U religiološkoj naučnoj periodici poznato je da migracije uveliko mijenjaju religijsku demografsku sliku u nekom društvu. Čovjek "jedne dimenzije” je prošlost, kao što je i društvo sa jednom kulturom, religijom, nacijom i sl. smješteno u prašnjave podrume istorije i zakržljale umove pojedinaca. Evropa je kontinent različitosti, riznica međusobno različitih i suprotnih tradicija. Postmoderna sa sobom nosi različitost, a to može da vodi ka podjelama. Stvorena je jedna "nova nepreglednost", kako kaže Habermas. Razložno tome, u posljednjem poglavlju autor iznosi činjenicu kako dolazi do miješanja različitih religija i kultura pa se otvaraju pitanja o ne/povjerenju među religijama, s pravom se nameće pitanje "predstavljaju li migranti prijetnju ili nadu"? To su, mislim, važna pitanja kojima sociologija religije treba da se pozabavi. U traženju odgovora autor apostrofira toleranciju. Međutim, tolerancija po sebi znači život jednih pored drugih, a ne jednih sa drugima. Multikulturalnost kao rješenje je opet upitno, budući da je multikulturalnost "geto, koji podrazumijeva više zatvorenost, nego poštovanje i suradnju”, smatra Cvitković. U potrazi za rješenjem, predlaže se otvorenost prema različitostima, pružiti ruku svima onima koji bi oplemenili Evropu svojim drugačijim iskustvima. Valjano je držati prozore otvorenim za sve vjetrove, piše Hajzinha. U multireligijskim društvima, kao jedno od rješenja predlaže se sekularnost, a to znači da se od migranata ne traži odustajanje od svoje religijske tradicije, već potiskivanje te i takve religijske tradicije iz javnog života.

Vrijeme je da prikaz privodim kraju, pa konstatujem da je ovo još jedna knjiga gdje svoja promišljanja i zamišljanja Cvitković ostavlja naučnoj i laičkoj publici na kritički osvrt. U ovom rukopisu se prepoznaje preporuka i mogući pogled ka dubokim slojevima na kojima se gradi naša stvarnost. Dragan Velikić tačno govori: "Iz knjige se ne može izaći, kada se jednom u nju uđe", a knjiga Ivana Cvitkovića je takva. Potpuno sam ubijeđen da ćemo još mnogo čuti i pročitati iz Cvitkovićeve radionice mudrosti, koje čitaoca nikako ne mogu ostaviti ravnodušnim, a knjiga koja je pred Vama, dragi čitaoče, sigurno je jedna od njih. Intelektualno je siromašniji onaj koji je ne pročita, a bogat je onaj koji korisne zapise iz knjige uvijek ima na umu. 